\title{
Haematological and biochemical parameters in Churra-da-Terra-Quente ewes from the northeast of Portugal
}

[Parâmetros hematológicos e bioquímicos de ovelhas da raça Churra da Terra Quente do nordeste de Portugal]

\author{
I.R. Dias $^{1,5}$, C.A. Viegas ${ }^{1,5}$, A.M. Silva ${ }^{2}$, H.F. Pereira ${ }^{2}$, C.P. Sousa ${ }^{1}$, P.P. Carvalho ${ }^{1}$, \\ A.S. Cabrita ${ }^{3}$, P.J. Fontes ${ }^{4}$, S.R. Silva ${ }^{4,6}$, J.M.T. Azevedo ${ }^{4,6}$ \\ ${ }^{1}$ Department of Veterinary Sciences - UTAD \\ P.O. Box 1013 \\ 5001-801 - Vila Real, Portugal \\ ${ }^{2}$ CITAB - Department of Biological and Environmental Engineering - UTAD - Vila Real, Portugal \\ ${ }^{3}$ Institute of Experimental Pathology - University of Coimbra - Coimbra, Portugal \\ ${ }^{4}$ Department of Animal Sciences - UTAD - Vila Real, Portugal \\ 53B's Research Group - Biomaterials, Biodegradables and Biomimetics, Ass. Lab.-IBB, Portugal \\ ${ }^{6} \mathrm{CECAV}$ - Center for Animal Sciences and Veterinary Studies - UTAD - Vila Real, Portugal
}

\begin{abstract}
Hematological and biochemical parameters, including plasma electrolytes and thyroid hormones, were determined in 73 clinically healthy Churra-da-Terra-Quente ewes, a typical breed from the northeast of Portugal. The hemogram values were: erythrocytes $9.8 \pm 1.5 \times 10^{12} / \mathrm{L}$; haemoglobin $118.1 \pm 19.1 \mathrm{~g} / \mathrm{L}$; haematocrit $40.8 \pm 5.9 \%$; leukocytes $5.7 \pm 1.8 \times 10^{9} / \mathrm{L}$; and platelets $544.3 \pm 177.2 \times 10^{9} / \mathrm{L}$. The thrombin time was $17.3 \pm 1.7$ seconds. The values of biochemical parameters were: total protein $76.4 \pm 6.1 \mathrm{~g} / \mathrm{L}$; glucose $2.87 \pm 0.60 \mathrm{mmol} / \mathrm{L}$; total cholesterol $1.65 \pm 0.33 \mathrm{mmol} / \mathrm{L}$; aspartate aminotransferase $155.9 \pm 49.2 \mathrm{U} / \mathrm{L}$; alanine aminotransferase 23.2 $\pm 9.6 \mathrm{U} / \mathrm{L} ; \gamma$-glutamyl transferase $48.0 \pm 18.7 \mathrm{U} / \mathrm{L}$; total alkaline phosphatase $121.6 \pm 76.1 \mathrm{U} / \mathrm{L}$; glutamate dehydrogenase $6.4 \pm 3.7 \mathrm{U} / \mathrm{L}$; urea $7.32 \pm 2.22 \mathrm{mmol} / \mathrm{L}$; creatinine $123.0 \pm 54.1 \mu \mathrm{mol} / \mathrm{L}$; total calcium $2.53 \pm 0.25 \mathrm{mmol} / \mathrm{L} ; \quad$ phosphorus $2.10 \pm 0.46 \mathrm{mmol} / \mathrm{L} ; \quad$ magnesium $1.01 \pm 0.09 \mathrm{mmol} / \mathrm{L} ; \quad$ sodium $152.04 \pm 3.65 \mathrm{mmol} / \mathrm{L}$; potassium $4.7 \pm 0.4 \mathrm{mmol} / \mathrm{L}$; ionized calcium $1.32 \pm 0.07 \mathrm{mmol} / \mathrm{L}$; total thyroxine $111.75 \pm 42.29 \mathrm{nmol} / \mathrm{L}$; total triiodothyronine $1.01 \pm 0.28 \mathrm{nmol} / \mathrm{L} ;$ free $\mathrm{T}_{4} 11.93 \pm 1.78 \mathrm{pmol} / \mathrm{L} ;$ free $\mathrm{T}_{3}$ $4.22 \pm 1.33 \mathrm{pmol} / \mathrm{L}$; and thyroid-stimulating hormone $0.18 \pm 0.19 \mu \mathrm{IU} / \mathrm{mL}$. Although differences among the Churra-da-Terra-Quente breed and other breeds may occur, the hematological and biochemical parameters, plasma electrolytes, and thyroid hormones, for this indigenous breed, were generally situated within the reference intervals previously reported for sheep.
\end{abstract}

Keywords: ewe, Portuguese Churra-da-Terra-Quente, hematological and biochemical parameters, electrolytes, thyroid hormone

\section{RESUMO}

Os valores hematológicos e bioquímicos, incluindo os eletrólitos plasmáticos e os hormônios da tireoide, foram determinados em 73 ovelhas, clinicamente saudáveis, da raça Churra da Terra Quente, raça ovina característica do nordeste de Portugal. Os valores obtidos para o hemograma foram: eritrócitos $9,8 \pm 1,5 \times 10^{12} / \mathrm{L}$; hemoglobina $118,1 \pm 19,1 \mathrm{~g} / \mathrm{L}$; hematócrito $40,8 \pm 5,9 \%$; leucócitos $5,7 \pm 1,8 \times 10^{9} / \mathrm{L}$ e plaquetas $544,3 \pm 177,2 \times 10^{9} / \mathrm{L}$. O tempo de trombina foi de 17,3 $\pm 1,7$ segundos. Os valores dos parâmetros bioquímicos avaliados foram: proteinas totais $76,4 \pm 6,1 \mathrm{~g} / \mathrm{L}$; glicose $2,87 \pm 0,60 \mathrm{mmol} / \mathrm{L}$; colesterol total 1,65 $\pm 0,33 \mathrm{mmol} / \mathrm{L}$; aspartato amino transferase 155,9 $\pm 49,2 \mathrm{U} / \mathrm{L}$; alanina amino transferase 23,2 $\pm 9,6 U / \mathrm{L} ;$ gama-glutamil

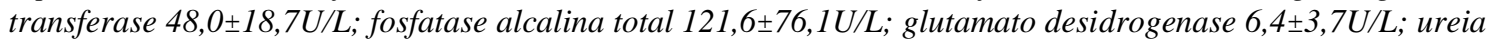

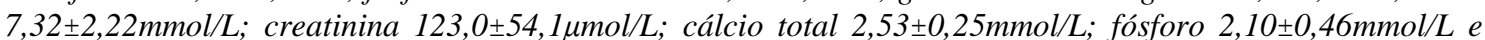
magnésio $1,01 \pm 0,09 \mathrm{mmol} / \mathrm{L} ; \quad$ sódio $152,04 \pm 3,65 \mathrm{mmol} / \mathrm{L}$; potássio $4,7 \pm 0,4 \mathrm{mmol} / \mathrm{L}$ e cálcio ionizado

Recebido em 11 de setembro de 2008

Aceito em 22 de fevereiro de 2010

E-mail: idias@utad.pt 
$1,32 \pm 0,07 \mathrm{mmol} / \mathrm{L} ;$ tiroxina total $111,75 \pm 42,29 \mathrm{nmol} / \mathrm{L} ;$ tri-iodotironina total $1,01 \pm 0,28 \mathrm{nmol} / \mathrm{L} ; T_{4}$ livre

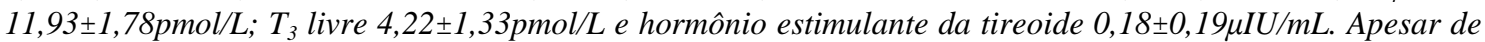
terem sido observadas algumas diferenças entre a raça Churra da Terra Quente e outras raças, os valores hematológicos e bioquímicos, eletrólitos plasmáticos e hormônios da tireóide, desta raça autóctone apresentam-se no geral situados dentro dos intervalos de referência publicados para a espécie ovina.

Palavras-chave: ovelha, Churra da Terra Quente, parâmetros hematológicos e bioquímicos, eletrólitos, hormônio da tiroide

\section{INTRODUCTION}

The Churra-da-Terra-Quente sheep is a typical breed from the northeast of Portugal, more specifically in the southern region of Trás-osMontes. The Churra-da-Terra-Quente sheep is an autochthonous breed, well fitted to its surroundings and to the seasonal variation in its food sources. The breed is medium-sized with coarse wool and high quality milk for cheese production. This breed is also characterized by its longevity, maternal qualities, and birth easiness. Its main skills are the production of lambs - the Terrincho lamb, and milk that is used in the production of the Portuguese Terrincho cheese, both with DOP - Denomination of Protected Origin (CEE regulation $\left.n^{\circ} 1107 / 96\right)$. In 2007 , the number of animals registered in the herdbook was of 26.848 , which belonged to 350 herds (breeders).

As variation among breeds may occur, determination of breed-specific reference intervals for haematological and biochemical values is of value in order to allow an accurate diagnosis of the potential pathological processes. This is particular useful in monitoring toxic or metabolic processes, nutritional deficiencies, and flock metabolic profiles.

In spite of the significant number of studies performed in the Churra-da-Terra-Quente sheep in the last few years, namely in the sheep carcass composition (Silva et al., 2006, 2007), the Terrincho lamb (Gomes et al., 2004; Silva et al., 2005; Santos et al., 2007), and the Terrincho cheese (Ferreira et al., 2006), there is a lack of published data on hematology and blood biochemistry of this particular breed.

Thus, the goals of the present study were to obtain better determination of a set of hematological and blood biochemical parameters, including plasma electrolytes and thyroid hormones as indicators of their metabolic status and hepatic, kidney, and thyroid functions of non-pregnant, and non-lactating Portuguese Churra-da-Terra-Quente ewe, kept in stockraising with free access to grass hay. Furthermore, this study also compared the obtained values for hematological and clinical biochemistry with previously published reference intervals for sheep.

\section{MATERIALS AND METHODS}

This study was conducted with seventy-three non-pregnant, and non-lactating healthy adult Portuguese Churra-da-Terra-Quente ewes, aging from two to seven-year-old and averaging $55 \mathrm{~kg}$. The animals were randomly chosen from the experimental flock of the University of Trás-osMontes e Alto Douro and raised in Vila Real (latitude $41^{\circ} 19^{\prime} \mathrm{N}$, longitude $7^{\circ} 44^{\prime} \mathrm{W}$ and altitude $479 \mathrm{~m}$ ), at Quinta de Prados, Portugal.

All animals were kept under the same management conditions. Before the beginning of the experiment, the animals were given an anthelmintic drench and an intramuscular injection of fat-soluble vitamins. The flock was permanently housed in a ventilated animal house and was fed once daily at 8:00am. The diet was based on grass hay fed ad libitum supplemented with $250 \mathrm{~g}$ of concentrate per animal. Diet was offered at an estimated $1.20 \mathrm{x}$ energy maintenance requirements according to the NCR (Nutrient..., 1985) recommendations. The composition of the foods is shown in Table 1. Animals had free access to water and trace mineralized salt. Samples of the hay and concentrate offered were weekly taken and were dried $\left(65^{\circ} \mathrm{C}, 24\right.$ hours) to determine dry matter (DM). Dried samples of foods were ground to pass a $1 \mathrm{~mm}$ screen for laboratory analyses. Ash, crude protein $(\mathrm{CP})$, and neutral detergent fiber (NDF) were analyzed according to AOAC (Official..., 1990). 
Table 1. Dry matter (DM) and chemical composition of feeds

\begin{tabular}{lcc} 
& \multicolumn{2}{c}{ Food } \\
\cline { 2 - 3 } & Grass hay & Concentrate \\
\hline DM $(\mathrm{g} / \mathrm{kg})$ & 88.5 & 90.4 \\
Chemical composition* (g/kg DM) & & 8.5 \\
Ash & 5.9 & 31.6 \\
NDF & 73.3 & 20.7 \\
CP & 6.1 & \\
\hline
\end{tabular}

${ }^{*} \mathrm{CP}$, crude protein; NDF, neutral detergent fiber.

Blood samples were collected by venipuncture of the jugular vein during spring, from 8:00 and 10:00am, before the first feeding, and repeated two weeks later. For the hematology study, hemogram tubes with EDTA (Sarstedt Monovette - Nümbrecht, Germany) were used, and for plasma obtainment, for the determination of thrombin time, tubes containing sodium citrate (Sarstedt - Monovette - 9NC) were used. To study the general biochemical and electrolyte parameters as well as the thyroid hormones, $20 \mathrm{~mL}$ of venous blood were collected into serum tubes containing no anticoagulant (Sarstedt Monovette - Serum Gel S). The plasma and serum were harvested within 30 minutes after collection by centrifugation at 3000rpm for 10 minutes. The hemogram and the thrombin time were immediately determined after the blood collection and the serum for general biochemical parameters and thyroid hormones determinations was rapidly harvested into $2 \mathrm{~mL}$ Eppendorf tubes and stored at $-20^{\circ} \mathrm{C}$.

The collection of blood samples for plasma electrolytes measurement was performed in total venous blood collected into a special $1 \mathrm{ml}$ syringe containing lyophilised lithium heparin normally used to obtain samples of arterial blood (RapidLyte $^{\mathrm{TM}}$, Chiron Diagnostics Corp. - East Walpole, USA). Immediately after collection, the needle was removed, the end of the syringe was covered with a luer cap, and the sample was thoroughly mixed for 20 to 30 seconds.

The hemogram was performed with an electronic cell counter, a semi-automated haematological analyzer (Sysmex $^{\text {TM }}$ F-800 - TOA Medical Electronics - Kobe, Japan) except the total white cell count that was manually performed in a Neubauer hemacytometer slide, and the differential counting by the microscopic identification of 200 white cells in blood smear stained by the Wright's staining method. The thrombin time was measured using a commercial available kit (Hemolab Thromb. Test BioMêrieux - Marcy l'Étoile, France) and its recommended protocol was performed in duplicate, according to instructions of the manufacturer.

General biochemical parameters were determined with commercially available immunoassay kits, namely for the measurement of glucose (Glucose Enzymatic PAP 1200 BioMêrieux), total cholesterol (Colesterol Enzymatic PAP 1200 - BioMêrieux), total protein (Total Protein - BioMêrieux), aspartate aminotransferase (AST - Enzyline ASAT/GOT 50 monoreactif - BioMêrieux), alanine aminotransferase (ALT - Enzyle ALAT/GPT 50 monoreactif - BioMêrieux), total alkaline phosphatase (ALP - Enzyline PAL optimise BioMêrieux), $\gamma$-glutamyl transferase $(\gamma$-GT $-20 \mathrm{~S}$ BioMêrieux), glutamate dehydrogenase (GLDH - Boehringer - Ingelheim, Germany), urea (Urea Cinétique - BioMêrieux), creatinine (Creatinine Cinétique - BioMêrieux), total calcium ( $\mathrm{Ca}-$ Ca-OCP - BioMêrieux), phosphorus (P Phosphorus UV - BioMêrieux), and magnesium $\left(\mathrm{Mg}^{2+}\right.$ - BioMêrieux) using a colorimetric method, by means of molecular absorbance spectrophotometry, and read with an automated biochemistry analyzer (Mascott Plus Model Lisabio, Pouilly-en-Aixois, France).

The determinations of the plasma electrolytes sodium $\left(\mathrm{Na}^{+}\right)$and potassium $\left(\mathrm{K}^{+}\right)$, and the free ionized form of calcium $\left(\mathrm{Ca}^{2+}\right)-$ were immediately processed after blood collection using an automated analyzer (IRMA SL series 2000 - Diametrics Medical Inc - St. Paulo, USA), the operation principle of which is based on ion-specific electrodes fixed in specific 
cartridges (IRMA SL, ADM R 1262 Diametrics Medical Inc).

The measurement of the thyroid hormones was performed with an automated biochemistry analyzer (Access Immunoassay System Beckman Instruments Inc - Chaska, USA), which operation principle is based on chemical luminescence. Commercially available immunoassay kits were used for total thyroxine $\left(\mathrm{T}_{4}-\right.$ ACCESS - Beckman Coulter - Fullerton, USA), free $\mathrm{T}_{4}$ (Beckman Coulter), total triiodothyronine $\left(T_{3}\right.$ Beckman Coulter), free $T_{3}$ (Beckman Coulter), and the thyroid-stimulating hormone (TSH - Hypersensitive hTSH Beckman Coulter).

All data were reported as mean \pm standard deviation (SD), range, and coefficient of variation $(\mathrm{CV})$. The determination of a normal distribution for each haematological and biochemical parameter was assessed by ShapiroWilk test and considered significant at $\mathrm{P}<0.05$. All statistical analyses were performed with a statistical software program XLSTAT 2008.2.03 (Addinsoft, Provalis Research, and Data Description Inc. - New York, USA).

\section{RESULTS AND DISCUSSION}

The hematological and biochemical results are presented in Tables 2 and 3, respectively. All data are reported as mean $( \pm \mathrm{SD})$, minimum, maximum, and $\mathrm{CV}$, for both Tables 2 and 3. The parameters that followed a normal distribution were RBC, HCT, MCH, MCHC, WBC, platelets, total protein, AST, ALT, total $\mathrm{Ca}, \mathrm{Mg}^{2+}, \mathrm{Na}^{2+}$, $\mathrm{Ca}^{2+}$, total and free $\mathrm{T}_{4}$, and free $\mathrm{T}_{3}$.

Table 2. Haematological parameters in Churra-da-Terra-Quente ewe and reported reference intervals for sheep

\begin{tabular}{|c|c|c|c|c|c|}
\hline \multirow{2}{*}{ Haematological parameters } & \multicolumn{4}{|c|}{ Churra-da-Terra-Quente ewe } & \multirow{2}{*}{$\begin{array}{l}\text { Ovine } \\
\text { specie } \\
\text { Reference }^{a}\end{array}$} \\
\hline & Minimum & Maximum & Means $( \pm \mathrm{SD})$ & $\mathrm{CV}$ & \\
\hline \multicolumn{6}{|l|}{ Red cell parameters } \\
\hline Red cell count $\left(\times 10^{12} / \mathrm{L}\right)$ & 5.4 & 12.3 & $9.8 \pm 1.5$ & 0.16 & $9-15$ \\
\hline Haemoglobin $(g / L)$ & 79 & 150 & $118.1 \pm 19.1$ & 0.16 & $90-150$ \\
\hline Haematocrit $(\%)$ & 23.5 & 53.0 & $40.8 \pm 5.9$ & 0.14 & $27-45$ \\
\hline Mean corpuscular volume (fL) & 32.4 & 46.4 & $41.6 \pm 3.0$ & 0.07 & $28-40$ \\
\hline Mean cell haemoglobin (pg) & 10.5 & 14.0 & $12.2 \pm 0.8$ & 0.07 & $8-12$ \\
\hline $\begin{array}{l}\text { Mean corpuscular haemoglobin concentration } \\
(\mathrm{g} / \mathrm{L})\end{array}$ & 250 & 344 & $292.0 \pm 17.8$ & 0.06 & $310-340$ \\
\hline \multicolumn{6}{|l|}{ White cell parameters } \\
\hline White cell count $\left(\times 10^{9} / \mathrm{L}\right)$ & 1.9 & 9.8 & $5.7 \pm 1.8$ & 0.32 & $4.0-12.0$ \\
\hline Neutrophils (band cells) $\left(\times 10^{9} / \mathrm{L}\right)$ & - & - & - & - & rare \\
\hline Neutrophils (polymorphonuclear) $\left(\times 10^{9} / \mathrm{L}\right)$ & 0.5 & 3.7 & $1.8 \pm 0.7$ & 0.41 & $0.7-6.0$ \\
\hline Lymphocytes $\left(\times 10^{9} / \mathrm{L}\right)$ & 1.2 & 5.8 & $3.3 \pm 1.2$ & 0.36 & $2.0-9.0$ \\
\hline Monocytes $\left(\times 10^{9} / \mathrm{L}\right)$ & 0 & 0.5 & $0.11 \pm 0.13$ & 1.10 & $0.0-0.75$ \\
\hline Eosinophils $\left(\times 10^{9} / \mathrm{L}\right)$ & 0 & 0.8 & $0.3 \pm 0.2$ & 0.72 & $0.0-1.0$ \\
\hline Basophils $\left(\times 10^{9} / \mathrm{L}\right)$ & - & - & - & - & $0.0-0.3$ \\
\hline \multicolumn{6}{|l|}{ White cell parameters (\%) } \\
\hline Neutrophils (segmented neutrophils) & 12 & 61 & $33.1 \pm 10.7$ & 0.32 & $10-50$ \\
\hline Neutrophils (band neutrophils) & - & - & - & - & rare \\
\hline Lymphocytes & 35 & 80 & $58.5 \pm 10.1$ & 0.17 & $40-75$ \\
\hline Monocytes & 0 & 7 & $2.3 \pm 1.9$ & 0.83 & $0-6$ \\
\hline Eosinophils & 0 & 13 & $5.1 \pm 2.9$ & 0.57 & $0-10$ \\
\hline Basophils & - & - & - & - & $0-3$ \\
\hline \multicolumn{6}{|l|}{ Other parameters } \\
\hline Platelets $\left(\times 10^{9} / \mathrm{L}\right)$ & 121 & 967 & $544.3 \pm 177.2$ & 0.33 & $\begin{array}{r}800-1.100 \\
(300-800) \mathrm{b}\end{array}$ \\
\hline Thrombin time (seconds) & 14 & 22 & $17.3 \pm 1.7$ & 0.10 & - \\
\hline
\end{tabular}

${ }^{\mathrm{a}}$ Kramer, J.W. (2000); ${ }^{\mathrm{b}}$ Meyer, J.D. and Harvey, J.W. (1998)

Values are means of two observations, with two-week interval, in each ewe. 
Table 3. General biochemical parameters and thyroid hormones in Churra-da-Terra-Quente ewe and reported reference intervals for sheep

\begin{tabular}{|c|c|c|c|c|c|}
\hline \multirow{2}{*}{ General biochemical parameters } & \multicolumn{4}{|c|}{ Churra-da-Terra-Quente ewe } & \multirow{2}{*}{$\begin{array}{c}\text { Ovine specie } \\
\text { Reference }\end{array}$} \\
\hline & Minimum & Maximum & Means $\pm \mathrm{SD}$ & $\mathrm{CV}$ & \\
\hline Glucose (mmol/L) & 1.70 & 4.53 & $2.87 \pm 0.60$ & 0.21 & $2.78-4.44 a, b$ \\
\hline Total cholesterol (mmol/L) & 0.8 & 2.6 & $1.65 \pm 0.33$ & 0.20 & $1.35-1.97 \mathrm{a}$ \\
\hline Total protein $(\mathrm{g} / \mathrm{L})$ & 63.1 & 88.1 & $76.4 \pm 6.1$ & 0.08 & $60.0-79.0 \mathrm{a}, \mathrm{b}$ \\
\hline Urea $(\mathrm{mmol} / \mathrm{L})$ & 2.7 & 11.3 & $7.32 \pm 2.22$ & 0.30 & $2.86-7.14 \mathrm{a}$ \\
\hline Creatinine $(\mu \mathrm{mol} / \mathrm{L})$ & 32.7 & 247.5 & $123.0 \pm 54.1$ & 0.44 & $106-168 a, b$ \\
\hline Aspartate aminotransferase (EC2.6.1.1.) (U/L) & 58 & 300 & $155.9 \pm 49.2$ & 0.32 & $60-280 \mathrm{a}$ \\
\hline Alanine aminotransferase (EC2.6.1.2) (U/L) & 5 & 46 & $23.2 \pm 9.6$ & 0.42 & $60-64 b$ \\
\hline$\gamma$-glutamyl transferase (EC2.3.2.2) (U/L) & 10 & 90 & $48.0 \pm 18.7$ & 0.39 & $20-52 a$ \\
\hline Total alkaline phosphatase (EC3.1.3.1.) (U/L) & 15 & 331 & $121.6 \pm 76.1$ & 0.63 & $68-387 a, b$ \\
\hline Glutamate dehydrogenase (EC1.4.1.3.) (U/L) & 3.2 & 10 & $6.4 \pm 3.7$ & 0.53 & $0-9 \mathrm{c}$ \\
\hline Total calcium (mmol/L) & 2.10 & 3.2 & $2.53 \pm 0.25$ & 0.10 & $2.88-3.20 \mathrm{a}$ \\
\hline Phosphorus (mmol/L) & 1.29 & 3.19 & $2.10 \pm 0.46$ & 0.22 & $1.62-2.36 a, b$ \\
\hline Magnesium (mmol/L) & 0.84 & 1.23 & $1.01 \pm 0.09$ & 0.09 & $0.90-1.31 \mathrm{a}$ \\
\hline \multicolumn{6}{|l|}{ Plasma electrolytes } \\
\hline Sodium (mmol/L) & 145.6 & 160.8 & $152.04 \pm 3.65$ & 0.02 & $139-152 a$ \\
\hline Potassium (mmol/L) & 3.87 & 5.67 & $4.7 \pm 0.4$ & 0.09 & $4.0-6.0 \mathrm{~b}$ \\
\hline Ionised calcium (mmol/L) & 1.15 & 1.47 & $1.32 \pm 0.07$ & 0.06 & $1.25-1.60 \mathrm{~d}$ \\
\hline \multicolumn{6}{|l|}{ Thyroid hormones } \\
\hline Total thyroxine (nmol/L) & 0 & 201.42 & $111.75 \pm 42.29$ & 0.38 & $38.6-77.2 \mathrm{e}$ \\
\hline Total triiodothyronine $(\mathrm{nmol} / \mathrm{L})$ & 0.56 & 1.7 & $1.01 \pm 0.28$ & 0.28 & $0.92-2.30 \mathrm{e}$ \\
\hline Free thyroxine (pmol/L) & 8.37 & 16.47 & $11.93 \pm 1.78$ & 0.15 & - \\
\hline Total triiodothyronine (pmol/L) & 1.0 & 6.59 & $4.22 \pm 1.33$ & 0.32 & - \\
\hline Thyroid-stimulating hormone $(\mu \mathrm{IU} / \mathrm{mL})$ & 0.02 & 0.68 & $0.18 \pm 0.19$ & 1.05 & - \\
\hline
\end{tabular}

In the present study of the Portuguese Churra-daTerra-Quente ewes, all the hematological parameters referring to the erythrocyte and leukocyte series and also to the blood platelet counting were, in general, within the reference intervals considered as normal for the ovine species. The importance of the determination of the hemogram lies basically in the fact that it allows the tracking of possible anomalies of the hematocrit (HCT), of the erythrocyte morphology, or also of the alterations in the total or differential counting of leukocytes. The HCT and the hemoglobin $(\mathrm{Hb})$ values are also relevant parameters in the demonstration of the protein state of the ruminants (Kramer, 2000). The interest in determining the thrombin time was based on the fact that this is one of the tests that characterize the final coagulation stage, working as an indicator of fibrinogen quantitative and/or qualitative disorders. This interest was also developed due to the fact that there are no references in the expertise literature to the reference interval for the thrombin time in the ovine species.
The values of the general clinical biochemistry parameters that were selected to help in the characterization of the metabolic and nutrition state and renal, hepatic, and thyroid functions, were also situated within the reference intervals published for the ovine species, with a few exceptions, namely the blood urea and the total $\mathrm{T}_{4}$ that were slightly higher than the maximum value and the calcaemia slightly below the minimum value of their corresponding reference intervals. This might be due to differences in nutrition and time of sampling in relation to feeding (Caldeira et al., 2007).

As far as the characterization of the energetic state of the ruminants is concerned, the glucose and the total cholesterol were evaluated, since these are determinations taken as a routine procedure, whose dosage protocols are currently implemented in the great majority of clinical analysis laboratories. However, it should be mentioned that one of the ideal sets on biochemical parameters for the definition of the energetic state of the ruminant consists in the simultaneous determination of glucose, $\beta$ hydroxybutyrate and, specially, of the free fatty 
acids (Caldeira et al., 2007). In association with theses parameters, the hormones insulin and glucagon are also referred as good energy status predictors (Caldeira et al., 2007). The level of glycaemia could contribute to the assessment of energy status diagnosis in association with insulin which has a close relationship with the nutritional state of the animal (McCann et al., 1992; Delavaud et al., 2002; Caldeira et al., 2007) and with respect to the free fatty acids, high levels generally indicate a negative energy balance (Delavaud et al., 2002; Caldeira et al., 2007), conversely low levels indicate a positive balance (Caldeira et al., 2007).

The protein state and the kidney function can be estimated in ewes by the simultaneous determination of the total protein and urea, associated with $\mathrm{HCT}$ and $\mathrm{Hb}$, and to the serum creatinine in the kidney function. Creatinine is mainly filtered by the kidney and there is littleto-no tubular reabsorption of creatinine. If the filtering process of the kidney is deficient, blood levels rise. Thus it constitutes a fundamental parameter in the evaluation of the kidney function since it is associated with creatinine metabolism and it is also involved in the storage and stabilization of elevated energy phosphate groups related with muscle energetic metabolism (Finco, 1997), and its serum level is not significantly affected by the ruminant diet (Finco, 1997; Caldeira et al., 1999; Sakkinen et al., 2001) or by alterations in the hepatic function or by the urea cycle (Finco, 1997). Considering the ruminant, it is important to notice that uremia might present itself diminished in a protein deficit situation, since it is highly influenced by the type of diet and also by the timing of the blood sample collection regarding the last meal (Caldeira et al., 1999, 2007).

Concentrations of the hepatic enzymes AST, $\gamma$ GT, ALP, and GLDH, in the present study were within the reference intervals, except for the ALT that was below the minimum range of the reference interval. However, ALT is of little value for the diagnosis of hepatocellular damage in ruminants, for this purpose it is preferable the determinations of the combination of AST, sorbitol dehydrogenase (SDH), and GLDH serum activities as specific hepatic enzymes of large animals (Tennant, 1997). However, the $\mathrm{SDH}$ represents a more complex determination and is not always available as a routine procedure. Therefore, in the present study, besides the assessment of the AST and GLDH serum activities, the authors have opted to determine the $\gamma$-GT and the ALP serum activities since these two biochemical parameters are used to indicate cholestasis (Tennant, 1997).

The levels of the main serum minerals, such as $\mathrm{Ca}, \mathrm{P}$, and $\mathrm{Mg}$, were determined for the evaluation of the mineral status of the organism, bearing in mind that the diagnosis of mineral deficiencies highly depends on the homeostatic control level of each mineral and on the time that the basic problem lasts. Calcium has various important functions, such as in the formation of the skeletal and dental tissues, muscle contraction, glycogen metabolic pathways, and hormones releasing; and phosphorus in cell functions, like in the ATP phosphate bonds formation for muscle contraction, neurological functions, and electrolyte transport (Rosol and Capen, 1997). Magnesium exists in skeletal tissues and it has also important functions in cell biology as a co-factor of near 300 cellular enzymes, its absorption and transport could be influenced by $\mathrm{Ca}$ and P (Chaney, 1997). The importance of the $\mathrm{Ca}^{2+}$ consists in the fact that about $50 \%$ of $\mathrm{Ca}$ from the extracellular and serum fluids are under the free ionized form, $\mathrm{Ca}^{2+}$, which is the biologically active fraction with vital functions on the cell physiology regulation level (Rosol and Capen, 1997).

In the evaluation of the hydro-electrolytic status of the organism, the plasma electrolytes were determined, $\mathrm{Na}^{+}$and $\mathrm{K}^{+}$, which are essential to the electrical activity of cellular membranes. Their concentration, regarding the plasma, the lymph, and the interstitial fluids, is mainly maintained by the fact that the excessive ingestion of these ions in the ruminant diet is eliminated by the kidney or the intestine (Carlson, 1997), bearing in mind that hydroelectrolytic disorders could be associated to food deprivation (Holtenius, 1990), beyond the water access restrictions or abnormal fluid loss. The dietary $\mathrm{K}$ is an important factor involved in the rumen adsorption of $\mathrm{Na}$, and hyponatraemia could develop during food deprivation, since ruminants normally ingest large quantities of $\mathrm{K}$ with the food, while the $\mathrm{Na}$ intake is smaller and because during feeding and rumination, large volumes of saliva with substantial quantities of $\mathrm{K}$ and $\mathrm{Na}$ enter the rumen (McDougall, 1948), 
being near $50 \%$ of the saliva $\mathrm{Na}$ reabsorbed in the rumen of sheep (Dobson, 1959).

The total and free $\mathrm{T}_{4}$ and $\mathrm{T}_{3}$, and the TSH were determined by the fact that the thyroid hormones are involved in the regulation of the basal metabolism of the majority of tissues and consequently in the metabolism of proteins, lipids, and carbohydrates, in the growth and bone maturing, and in the regulation of the reproductive processes (Ruckebush et al., 1991). In the present study, the obtained value for total $\mathrm{T}_{4}$ was slightly situated above the maximum value of the reference interval released for ovine species and, on the contrary, the total $\mathrm{T}_{3}$ was situated within the reference interval for the ovine species, but near its inferior limit. A possible reason for this can be associated with the cattle raising conditions referred to the nutrition status of the ewes and to the seasonal changes. In fact, the expertise literature describes a correlation between the nutrition level and the thyroid hormones, generally animals having inadequate food reported to have low levels of serum $\mathrm{T}_{4}$ and $\mathrm{T}_{3}$, relating the thyroid activity and energy balance in this species, representing the circulating thyroid hormones a relevant metabolic index of the nutritional status (Caldeira et al., 2000; Delavaud et al., 2002; Caldeira et al., 2007). Thyroid hormones have particular importance in the seasonal reproductive cycle of sheep, since they are required for seasonal suppression of gonadotropin-releasing hormone and luteinizing hormone secretion, maintaining an annual rhythm in the reproductive activity (Viguié et al., 1999; Rosa and Bryant, 2003), by acting directly within the brain promoting seasonal inhibition of neuroendocrine reproductive function in ewe (Viguié et al., 1999).

\section{CONCLUSION}

It has been shown that the values of hematological and biochemical parameters, including plasma electrolytes and thyroid hormones, in Portuguese Churra-da-TerraQuente ewes fed according to the NRC recommendations were generally situated within the reference intervals previously reported for sheep. Due to the shortage of bibliographical data and other studies on the hematology and clinical biochemistry of the Portuguese Churrada-Terra-Quente ewes, the values of these parameters in healthy animals will provide a basis for diagnosis purposes in this breed.

\section{REFERENCES}

CALDEIRA, R.M.; ALMEIDA, M.A.; SANTOS, C.C. et al. Daily variation in blood enzymes and metabolites in ewes under three levels of feed intake. Can. J. Anim. Sci., v.79, p.157-164, 1999.

CALDEIRA, R.M.; BELO, A.T.; SANTOS, C.C. et al. The effect of long-term feed restriction and over-nutrition on body condition score, blood metabolites and hormonal profiles in ewes. Small Rum. Res., v.68, p.242-255, 2007.

CALDEIRA, R.M.; VAZQUES, M.I.; VAZ PORTUGAL, A. Daily profiles of blood insulin, insulin-like growth factor-I, thyroxine and triiodothyronine in ewes under three levels of feed intake. Asian-Australian J. Anim. Sci., v.13, p.1121-1126, 2000.

CARLSON, G.P. Fluid, Electrolyte, and acidbase balance. In: KANEKO, J.J.; HARVEY, J.W.; BRUSS, M.L. (Eds). Clinical biochemistry of domestic animals. 5.ed. San Diego: Academic, 1997. p.485-516.

CHANEY, S.G. Principles of nutrition II: Micronutrients. In: DEVLIN, T.M. (Ed). Textbook of biochemistry with clinical correlations. 4.ed. New York: Wiley Liss, Inc., 1997. p.1107-1136.

DELAVAUD, C.; FERLAY, A.; FAULCONNIER, Y. et al. Plasma leptin concentration in adult cattle: effects of breed, adiposity, feeding level, and meal intake. $J$. Anim. Sci., v.80, p.1317-1328, 2002.

DOBSON, A. Active transport through the epithelium of the reticulo-rumen sac. J. Physiol., v.146, p.235-251, 1959.

FERREIRA, I.M.; VEIROS, C.; PINHO, O. et al. Casein breakdown in terrincho ovine cheese: comparison with bovine cheese and with bovine/ovine cheeses. J. Dairy Sci., v.89, p.2397-2407, 2006.

FINCO, D.R. Kidney function. In: KANEKO, J.J.; HARVEY, J.W.; BRUSS, M.L. (Eds). Clinical biochemistry of domestic animals. 5.ed. San Diego: Academic, 1997. p.441-484. 
GOMES, M.J.M.; DIAS-DA-SILVA, A.A.; AZEVEDO, J.M.T. et al. Response of lambs fed wheat-straw diets to supplementation with soybean hulls. Aust. J. Agr. Res., v.55, p.261272,2004

HOLTENIUS, K. Plasma electrolyte concentration in food-deprived goats orally supplemented with potassium chloride. Brit. J. Nutr., v.64, p.211-218, 1990.

KRAMER, J.W. Normal haematology of cattle, sheep, and goat. In: FELDMAN, B.F.; ZINKL, J.G.; JAIN, N.C. (Eds). Schalm's veterinary haematology. 5.ed. Philadelphia: Lippincott Williams \& Wilkins, 2000. p.1075-1084.

MCCANN, J.P.; BERGMAN, E.N.; BEERMANN, D.H. Dynamic and static phases of severe dietary obesity in sheep: food intakes, endocrinology and carcass and organ chemical composition. J. Nutr., v.122, p.496-505, 1992.

MCDOUGALL, E.I. The composition and output of sheep's saliva. Biochem. J., v.43, p.99-109, 1948 .

MEYER, J.D.; HARVEY, J.W. Reference intervals for haematology and serum chemistry values for adult animals expressed in SI units (Appendixes). In: MEYER, J.D.; HARVEY, J.W. (Eds). Veterinary laboratory medicine Interpretation \& Diagnosis. 2.ed. Philadelphia: W.B. Saunders, 1998. p.348-349.

NUTRIENT Requirements of Sheep. 6.ed. Washington, DC: National Academic, 1985.

OFFICIAL methods of analysis. 14.ed. Washington DC: AOAC, 1990.

ROSA, H.J.D.; BRYANT, M.J. Seasonality of reproduction in sheep. Small Rum. Res., v.48, p.155-171, 2003.

ROSOL, T.J.; CAPEN, C.C. Calcium-regulating hormones and diseases of abnormal mineral (calcium, phosphorus, magnesium) metabolism. In: KANEKO, J.J.; HARVEY, J.W.; BRUSS, M.L. (Eds). Clinical biochemistry of domestic animals. 5.ed. San Diego: Academic, 1997. p.619-702.
RUCKEBUSH, Y.; PHANEUF, L.P.; DUNLOP R. Thyroid metabolism hormones. In: RUCHEBUSH, Y.; PHANEUF, L.P.; DUNLOP, R. (Eds). Physiology of small and large animals. Philadelphia: B.C. Decker, 1991. p.513-520.

SAKKINEN, H.; STIEN, A.; HOLAND, O. et al. Plasma urea, creatinine, and urea: creatinine ratio in reindeer (Rangifer tarandus tarandus) and in svalbard reindeer (Rangifer tarandus platyrhynchus) during defined feeding conditions and in the field. Physiol. Biochem. Zool., v.74, p.907-916, 2001.

SANTOS, V.A.C.; SILVA, S.R.; MENA, E.G.; AZEVEDO, J.M.T. Live weight and sex effects on carcass and meat quality of "Borrego Terrincho-PDO" suckling lambs. Meat Sci., v.77, p.654-661, 2007.

SILVA, S.R.; AFONSO, J.J.; SANTOS, V.A. et al. In vivo estimation of sheep carcass composition using real time ultrasound with two probes of 5 and $7.5 \mathrm{MHz}$ and image analysis. $J$. Anim. Sci., v.84, p.3433-3439, 2006.

SILVA, S.R.; GOMES, M.J.; DIAS-DA-SILVA, A.A. et al. Estimation in vivo of the body and carcass chemical composition of growing lambs by real-time ultrasonography. J. Anim. Sci., v.83, p.350-357, 2005.

SILVA, S.R.; GUEDES, C.M.; SANTOS, V.A. et al. Sheep carcass composition estimated from Longissimus thoracis et lumborum muscle volume measured by in vivo real-time ultrasonography. Meat Sci., v.76, p.708-714, 2007.

TENNANT, B.C. Hepatic function. In: KANEKO, J.J.; HARVEY, J.W.; BRUSS, M.L. (Eds). Clinical biochemistry of domestic animals. 5.ed. San Diego: Academic, 1997. p.327-352.

VIGUIÉ, C.; BATTAGLIA, D.F.; KRASA, H.B. et al. Thyroid hormones act primarily within the brain to promote the seasonal inhibition of luteinizing hormone secretion in the ewe. Endocrinology, v.140, p.1111-1117, 1999. 